\title{
The RCA (Revealed Comparative Advantage) and IO (Index of Openness) of Nebraska and Japanese Trade, 2000-2015
}

\author{
Vani Kotcherlakota and Michael Lundeen \\ Nebraska Department of Economic Development, Lincoln, NE \\ Email: vani.kotcherlakota@nebraska.gov
}

\begin{abstract}
This article analyzes the key elements of Nebraska and Japanese trade for the years 20002015. In addition to detailing trade, the emphasis is on obtaining estimates for the Index of Openness (IO) and Revealed Comparative Advantage (RCA) for selected Japanese and Nebraska products. The main conclusion of the study is that Nebraska's food manufactures exports are vital to keeping Nebraska's economy productive and competitive. The state, therefore, has an economic interest in continuing to promote and encourage trade with Japan.
\end{abstract}

Keywords: Index of Openness, Revealed Comparative Advantage, Nebraska, exports, imports, Japan

\section{Introduction}

The objective of the paper is to analyze trade between Japan and Nebraska for the years 2000 to 2015. The discussion is in four sections. First, we compare selected geographic and demographic characteristics of Nebraska and Japan. The second section contains brief descriptions of the trade and cultural agreements between Nebraska and Japan. The third section describes the methodology and data used in this analysis. In the fourth section, we present the results and conclusions.

\section{The Geography and Demography of Nebraska and Japan}

Japan is an eastern Asian island chain surrounded by the Sea of Japan; Nebraska is a landlocked state in the middle of the North American continent. So, are there any commonalities between these two entities on different sides of the globe?

The total land area of Nebraska is $198,974 \mathrm{sq}$. km., or equal to 52.7 percent of the total land area of Japan which is $377,915 \mathrm{sq}$. $\mathrm{km}$. Japan is slightly smaller than the state of California. Only 11.7 percent of Japan is arable land; whereas 48.0 percent of Nebraska's 183.44 sq. km. of land in farms was harvested in 2012. Historically, the lack of arable land has been a key to determining Japan's domestic and foreign policies.

Japan not only is physically larger than Nebraska, it has a much larger population - in 2015, its estimated population was $126,919,659$ which ranked $11^{\text {th }}$ in the world and equals 335.8 persons per sq. $\mathrm{km}$. Nebraska's population estimate in 2015 was $1,896,190$ which equals 9.5 persons per sq. km. So, Japan is 35 times more densely settled than Nebraska. Nebraska's population growth rate was an estimated 0.8 percent between 2014 and 2015; Japan's by comparison was -0.16 percent. That means Japan's population actually declined by an estimated 200,000 people between 2014 and 2015 -- deaths exceeded births and net inmigration was zero. In 2014, an estimated 50.2 percent (slightly over half) of the Nebraska population was female. Japan had a 2015 birth rate of 7.9 births per thousand, which ranked $222^{\text {nd }}$ in the world. So, Japan's working age population is not replacing itself.

Japan's labor force is obviously much larger than Nebraska's - an estimated 65.9 million in 2014 compared to a total employment of 830,073 in 2013 in Nebraska. Japan's labor force ranked ninth in the world. In 2014, 70.2 percent of the 16 years and older Nebraska population was in the labor force; and 65.6 
percent of the 16 years and older female population was in the labor force. In 2015, the estimated per capita gross domestic product for Japan was $\$ 38,100$ compared to $\$ 60,120$ for Nebraska. ${ }^{[1]}$

So, do Japan and Nebraska have anything in common? Yes, their trading relationship. Because of Japan's comparatively large population and small amount of arable land, Japan currently imports ". . . about $60 \%$ of its food on a caloric basis." Nebraska's large exports of food products to Japan contribute to the country meeting its food importation needs. ${ }^{[2]}$

\section{$3 \quad$ Nebraska-Japan Trade and Cultural Relationship}

Nebraska has strong trade and cultural relationships with Japan. Japan accounts for 31 of the state's foreign owned businesses. The country is the state's third largest export market with over 120 Nebraska companies actively involved in trade with Japan. Product areas are diverse, and include: automotive parts and supplies, medical/surgical equipment and supplies, educational materials, water purification systems, lawn maintenance equipment, sporting goods, electronic equipment \& components, and grain handling and storage equipment.

Nebraska has had long-term relationships with several Japanese cities. Shizouka is Omaha's first sister city, and 2005 was the $40^{\text {th }}$ anniversary of their relationship. Hastings has had a Sister City relationship with Ozu for over 10 years. The Omaha/Shizuoka Sister city partnership began in 1965 and initially concentrated on educational exchanges. That relationship has grown into a relationship between the state of Nebraska and Shizuoka Prefecture. While there are still efforts to strengthen the cultural and educational ties, there is currently an emphasis on economic development efforts and medical technology exchanges.

Since 1991, the Nebraska governor has led seven trade missions to Japan. In 2004, Governor Ishikawa led a Shizuoka Prefecture mission to Nebraska. Nebraska currently has an Honorary Commercial Attaché in Osaka, representing the state in the Kansai area. The state has had that representation since 1985.

Nebraska has been a member of the Midwest U.S.-Japan Association since 1987, and hosted the annual conference in 1999. Nebraska also has a Japanese school in Omaha for Japanese families to send their children to learn the Japanese language and culture (Source: Nebraska Department of Economic Development Website, 2016).

\section{$4 \quad$ Methodology and Data}

\subsection{Methodology}

The tables and figures that follow depict the flow of imports and exports between the two nations. We used two simple statistical tools, the Index of Openness and the Revealed Comparative Advantage, to analyze the composition of trade between Nebraska and Japan.

\subsection{Index of Openness}

The Index of Openness (IO) indicator is defined (at current prices, current exchange rates) as:

$$
\frac{\text { Imports }+ \text { Exports (both goods and services) }}{\text { Gross Domestic Product }}
$$

[1] This discussion of the Japanese and Nebraska demographic and population characteristics is based on the facts and figures in the CIA, World Fact Book, 2016 and U.S. Census Bureau State Profile data.

[2] "Deficient in the production of many natural resources, Japan has long been dependent on imported raw materials. . . . A small agricultural sector is highly subsidized and protected, with crop yields among the highest in the world. While self-sufficient in rice production, Japan imports about $60 \%$ of its food on a caloric basis" (CIA, World Fact Book, 2016). 
Goods consist of merchandise imports and exports. Services cover transport, travel, communications, construction, IT, financial, other business, personal, and government services as well as royalties and license fees.

The trade to Gross Domestic Product (GDP) ratio is the sum of exports and imports divided by GDP. This indicator measures an economy's 'openness' or 'integration' with the world economy. It is the combined weight of total trade in an economy, and is a measure of the degree of dependence of domestic producers on foreign markets and their trade orientation (for exports) and the degree of reliance of domestic demand on the foreign supply of goods and services (imports). The IO Index indicates the degree to which an economy is dependent on foreign markets for its growth. ${ }^{[3]}$

Trade is vital to any successful modern economy. It is crucial for the competitiveness of the Japanese and Nebraska economies in the long run. By exposing firms and products to international competition, economies are encouraged to focus on areas of comparative advantage. ${ }^{[4]}$ That insures that scarce skills and resources are deployed where they are most productive. Moreover, trade increases competition, enables firms to capitalize on economies of scale by providing access to larger markets, and encourages the spread of skills, knowledge, and innovation. The IO will be influenced not only by the trade policies adopted by the country or state in question and the result of multilateral trade negotiations, but also by the state of the world economy. $\left[{ }^{5}\right]$

\subsection{Revealed Comparative Advantage}

The Revealed Comparative Advantage (RCA) is a trade analysis tool to measure and assess the competitive advantage of the products which a country exports. The RCA indicates whether a country's product has trade potential or has a simple competitive advantage.

where

$$
\mathrm{RCAij}=(\mathrm{Xij} / \mathrm{Xi}) /(\mathrm{Xaj} / \mathrm{Xa})
$$

$$
\begin{gathered}
\mathrm{Xij}=\text { exports of product } \mathrm{j} \text { from country } \mathrm{i} \\
\mathrm{X} \mathrm{i}=\text { total exports from country } \mathrm{i} \\
\mathrm{Xaj}=\text { total exports of product } \mathrm{j} \text { from the world } \\
\mathrm{Xa}=\text { total exports of the world. }
\end{gathered}
$$

The numerator is the share of good $\mathrm{i}$ in the exports of country, while the denominator is the share of good $\mathrm{i}$ in the exports of the world.

The reason for calculating the IO is to examine how open the Nebraska and Japanese economies are to trade; the RCA calculations identify which commodities are or would be beneficial to trade.

\subsection{Data}

In order to analyze the trade between Nebraska and Japan, the following variables were used for the periods given in the parentheses.

- Value of Nebraska Exports to Japan (2000-2015)

- Value of Nebraska Imports from Japan (2008-2015)

- Value of Nebraska Commodity Exports to Japan (2012-2015)

- Value of Nebraska Commodity Imports from Japan (2012-2015)

- Value of Top three Nebraska Commodity exports to Japan (2010-2015)

- Value of Nebraska's Top Four Commodity Imports from Japan (2008-2015)

- Commodity Composition of Nebraska exports to Japan (2012-2015)

- Commodity Composition of Nebraska imports from Japan (2012-2015)

${ }^{[3]}$ United Kingdom, Department for Business Innovation \& Skills, BIS Performance Indicators, 2015.

${ }^{[4]}$ Bela Balassa, "Trade Liberalization and 'Revealed Comparative Advantage," Manchester School 33; 99-123, 1965.

${ }^{[5]}$ Vani V. Kotcherlakota and M. Rittenhouse, "Index of Openness: Measurement and Analysis," The Social Science Journal 37(1):125-130, 2000. 
- Japan's High Technology exports to world (2006 - 2015)

- Japan's service exports to world (2006 - 2015)

- Japan's merchandise exports to world (2006 - 2015)

- Japan's manufacturing exports to the world (2009-2015)

- Japan's Gross Domestic Product (2005-2013)

- World's exports of Goods and services (2012 and 2013)

- World's Merchandise exports (2006-2015)

- World's High Technology exports (2006 and 2015)

- World's Service exports (2006 and 2015)

- World's Manufactures Exports (2009-2013)

The choice of the period for each variable was dictated by data availability. The definitions of these variables are given in the sources from which the data were obtained. The principal source was the World Bank Databank, which did not have the most recent numbers for every variable.

\section{$5 \quad$ Results and Analysis}

In this section, the analysis and results are presented. Figures 1 and 2 reveal that Nebraska's exports to Japan have been steadily increasing since 2004. Imports have grown as well, but the levels of state imports from Japan are much lower than export levels (about half the values).

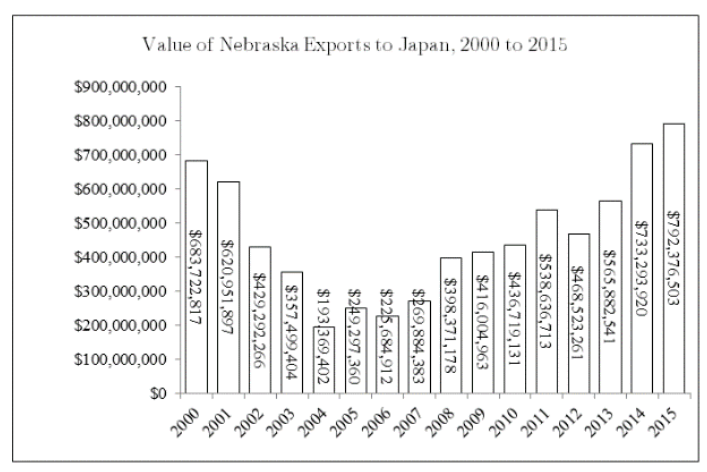

Figure 1. Value of Nebraska exports to Japan, 2000 to 2015. Source: USDOC, International Trade Administration, 2016

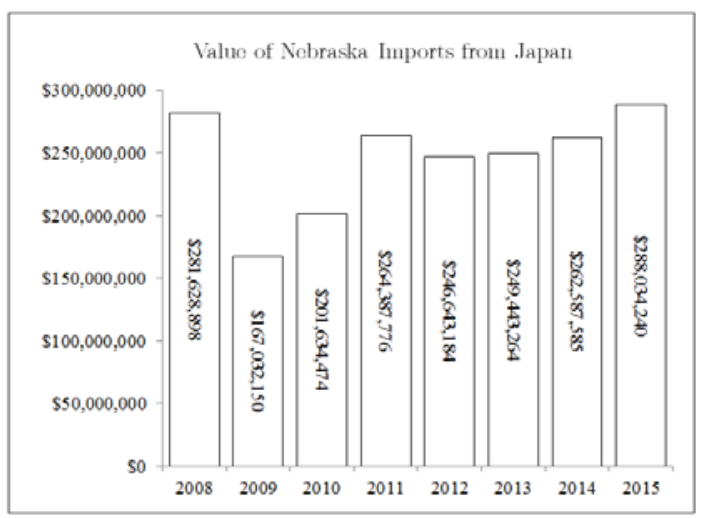

Figure 2. Value of Nebraska imports from Japan. Source: USDOC, International Trade Administration, 2016 
The principal Nebraska commodity exports to and imports from Japan are presented in Figures 3 and 4. The top four exports in 2015 were Food Manufactures, Electrical Equipment, Computer Products, and Chemicals. Nebraska's top four imports from Japan were Machinery (except electronic); Chemicals; Transportation Equipment; and Fabricated Metal Products. In 2015, food manufactures exports represented 52.3 percent of total Nebraska exports to Japan. That was considerably below the 76.0 percent of total exports that food manufactures averaged between 2000 and 2015. In every year between 2000 and 2015, food exports occupied the top position whereas, in the case of imports, fluctuations occurred in commodity rankings for the period 2008 to 2015. The major commodities imported by Nebraska from Japan are Machinery (except Electrical), Chemicals, and Transportation Equipment. Chemicals and Transportation Equipment increased steadily from 2011 to 2015, whereas Machinery imports declined.

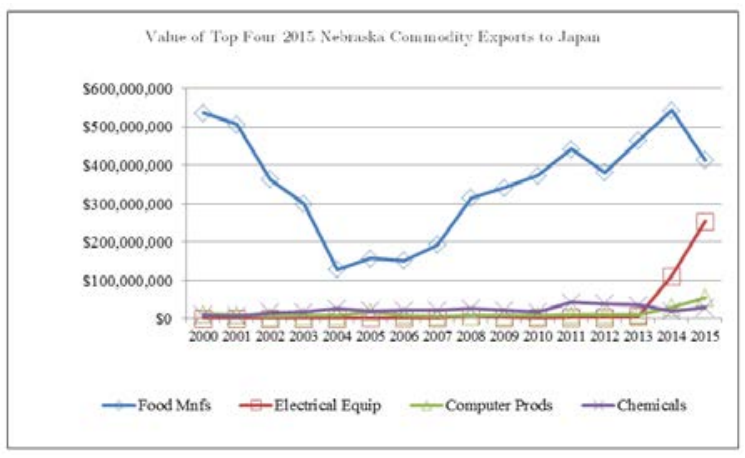

Figure 3. Value of top four 2015 Nebraska commodity exports to Japan. Source: USDOC, International Trade Administration, 2016

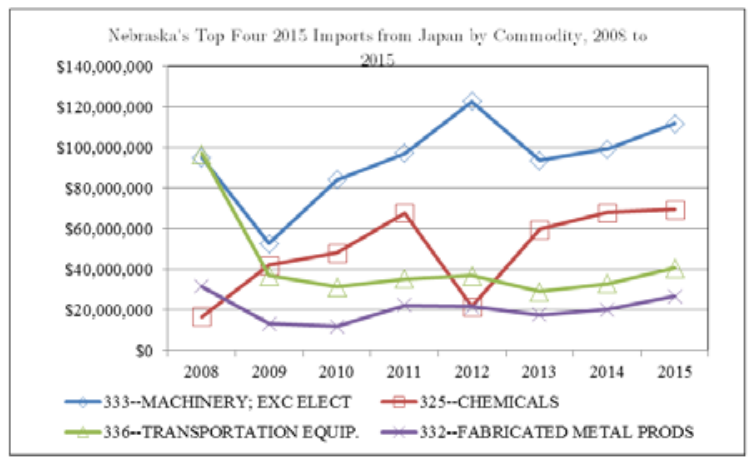

Figure 4 - Nebraska's top four 2015 imports from Japan by commodity. Source: USDOC, International Trade Administration, 2016

For comparison purposes, Table 1 presents the total value of U.S. and selected states' exports to and imports from Japan for the years 2012 to 2015. With respect to exports, there was a steady increase in the period in Nebraska exports, while nationally there was a decline in total U.S. exports to Japan. The state's rank in value of exports improved from 32 in 2012 to 25 in 2014 when compared to other U.S. states. Imports also exhibited an increasing trend as the state's rank changed from 36 in 2012 to 35 in 2015. (California led all states in the value of Japanese exports and imports with 18.3 percent of total U.S. exports to Japan in 2014 and 28.6 percent of total U.S. imports from Japan.) 
Table 1. U.S. exports to and imports from Japan by selected state, 2012 to 2015

\begin{tabular}{|c|c|c|c|c|c|c|c|c|}
\hline \multirow{2}{*}{$\begin{array}{l}\text { Year } \\
\text { Item }\end{array}$} & \multicolumn{2}{|l|}{$\underline{2012}$} & \multicolumn{2}{|l|}{$\underline{2013}$} & \multicolumn{2}{|l|}{$\underline{2014}$} & \multicolumn{2}{|l|}{$\underline{2015}$} \\
\hline & Value $(1,000 s)$ & Rank & Value(1,000s) & Rank & Value $(1,000 \mathrm{~s})$ & Rank & Value(1,000s) & Rank \\
\hline \multicolumn{9}{|c|}{ Exports - Japan: } \\
\hline U.S. & $\$ 69,975,786$ & -- & $\$ 65,216,087$ & -- & $\$ 66,827,397$ & -- & $\$ 62,471,831$ & -- \\
\hline California & $13,047,324$ & 1 & $12,735,099$ & 1 & $12,212,020$ & 1 & $11,740,973$ & 1 \\
\hline Nebraska & 468,523 & 32 & 565,882 & 29 & 733,293 & 25 & 792,376 & 24 \\
\hline North Dakota & 33,796 & 50 & 31,948 & 50 & 36,739 & 50 & 40,905 & 49 \\
\hline \multicolumn{9}{|c|}{ Imports - Japan: } \\
\hline U.S. & $\$ 146,431,693$ & -- & $\$ 138,574,412$ & -- & $\$ 134,003,716$ & -- & $\$ 131,111,974$ & -- \\
\hline California & $41,472,724$ & 1 & $38,383,521$ & 1 & $38,285,217$ & 1 & $38,503,156$ & 1 \\
\hline Nebraska & 246,643 & 36 & 249,443 & 34 & 262,587 & 34 & 288,034 & 35 \\
\hline North Dakota & 88,685 & 44 & 73,204 & 42 & 48,601 & 45 & 36,843 & 47 \\
\hline
\end{tabular}

Source: U.S. Department of Commerce, USA Trade Online, 2016

The RCA for Nebraska manufacturing exports was more than one for the years 2009 to 2015 (Figure 5). That means Nebraska manufacturing exports represented a higher proportion of the state's total exports than Japan's manufacturers' exports. The RCAs for selected Japanese export categories compared to the world are in Figure 6. The RCAs reveal that the values are less than one for Service exports. The RCAs are much higher for High Tech and Merchandise Exports. As a matter of fact, the RCA calculated for Japan's Manufacturing Exports to the world (Figure 7) increases in value until 2011 and then declines sharply.

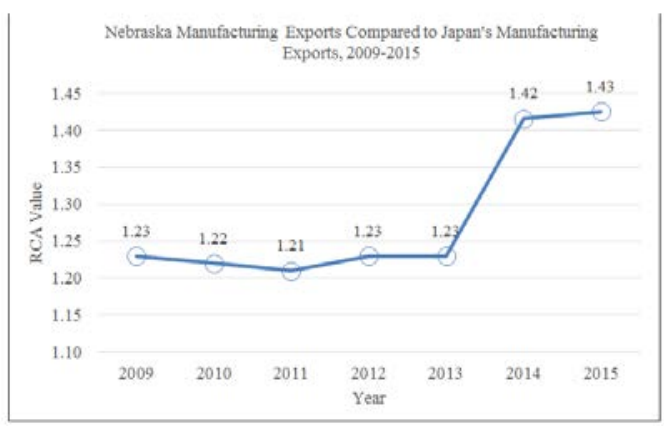

Figure 5. Nebraska manufacturing exports compared to Japan's manufacturing exports. Source: World Bank, Databank, 2016

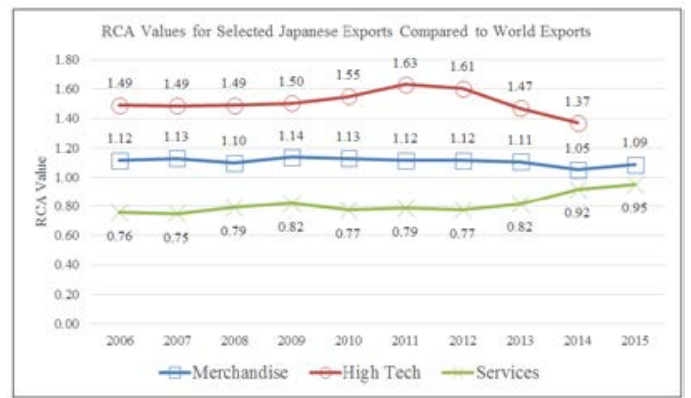

Figure 6 - RCA values for selected Japanese exports compared to world exports. Data from World Bank, World Development Indicators, 2016: calculations by NDED 


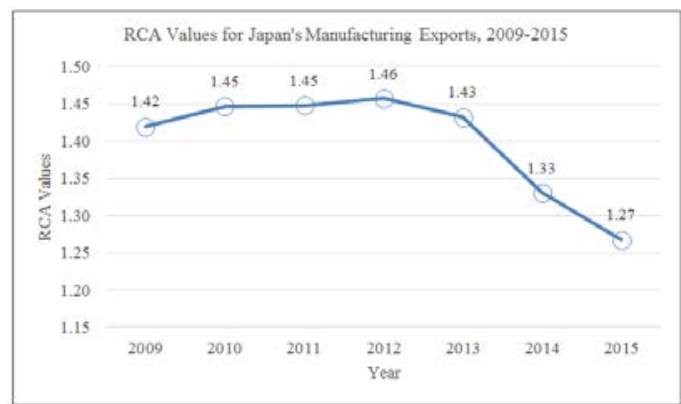

Figure 7 - RCA values for Japan's manufacturing exports. Data source: World Bank, Databank, 2016; calculations by NDED

The IO values for Japan from 2005 to 2015 are presented in (Figure 8). The values fluctuated over time and yielded low values to start, but have risen in recent years. According to Leamer's study, Japan ranked $13^{\text {th }}$ in the world, using the Trade Openness Index, a slightly different openness measure. The EU Cham (European Chamber) calculated the Trade Openness Index (2014) for 43 countries in Europe. The range was from a low of 43 for Russia and to a high of 180 for Slovakia. ${ }^{[6]}$

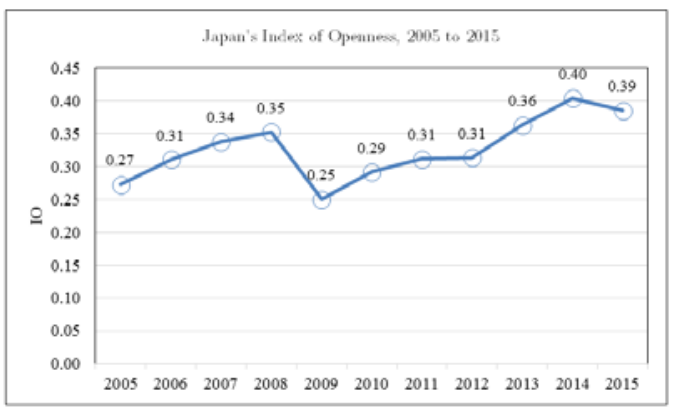

Figure 8 - Japan's index of openness. Data source: World Bank, Databank, 2016; calculations by NDED

But, in general, it is difficult to compare these results with other studies as the specific regions are not the same nor are the time periods. Balassa and Noland did a study on "Revealed Comparative Advantage in Japan and United States."[7] Their conclusion was that, during the period 1967-1983, Japan's patterns of specialization was found to have changed dramatically with Japan shifting from specialization in unskilled labor intensive goods to human capital intensive products while its comparative disadvantage increased in natural resources intensive products. Another study by Langhammer revealed that, when compared to the U.S. and the EU, the RCA for trade in services was quite weak for Japan. ${ }^{[8]}$

${ }^{[6]}$ Edward E. Leamer, Measures of Openness, National Bureau of Economic Research, (pp. 145-204), 1988, and EuCham Research Department, Compiled by Mai Nguyen, "2015-11 Trade Openness Index - EuCham European Chamber," 2015. [7] Bela Balassa, "'Revealed' Comparative Advantage Revisited: An Analysis of Relative Export Shares of the Industrial Countries, 1953 - 1971, "Manchester School 45: 327-44, 1967 and Marcus Noland, “'Revealed' Comparative Advantage in Japan and the United States," Journal of International Economic Integration, Vol. 4, No. 2, pp. 8-22, Autumn 1989.

${ }^{[8]}$ Rolf J. Langhammer, "Revealed comparative advantages in services trade of the United States, the European Union and Japan" what do they tell us? The Journal of World Investment and Trade, ISSN 1660-7112, Vol. 5, Iss. 6, pp. 887$896,2004$. 


\subsection{Summary}

- Nebraska exports to Japan declined from 2000 to 2003 and then steadily increased (Figure 1).

- With respect to imports, they declined from 2008 to 2009 then steadily increased but at a much lower levels than exports to Japan (Figure 2).

- The top four Nebraska commodity exports to Japan were Food Manufactures, Electrical Equipment, Computer and Electronic Products, and Chemicals (Figure 3).

- In Table 1, the value of state exports and imports is provided for the U.S. and selected states. Nebraska's rank for exports to Japan changed from 32 in 2012 to 29 in 2013, to 25 in 2014, and to 24 in 2015. As for imports, Nebraska ranked $36^{\text {th }}$ among the fifty states in value of imports from Japan in $2012,34^{\text {th }}$ in $2013,34^{\text {th }}$ in 2014 , and $35^{\text {th }}$ in 2015.

- Commodity analysis of exports revealed that Food Manufactures occupied the top rank followed by Electrical Equipment; Appliances \& Components (Table 1). In the case of commodity imports, Machinery ranked number one, followed by Chemicals and Transportation Equipment.

- The RCAs for Nebraska manufactured exports are shown in Figure 5. This index yielded values greater than one for most of the years between 2009 and 2015, which implies that those exports are significant and relevant compared to Japan's manufacturing exports. Figure 6 deals with the RCAs for selected Japanese export categories and, interestingly, the data reveal that High Tech exports have a higher RCA than Merchandise or Services exports, even though high tech exports make up a smaller percentage of total exports than the other two categories. ${ }^{[9]}$ Figure 7 shows Japan's RCA for Manufacturing Exports, increased from 2009 to 2012, then declined through 2015.

- Figure 8 shows the openness of Japan to international transactions. The index value was low which suggests Japan depends on its domestic economy for growth rather than international trade.

\subsection{Conclusion}

We noted earlier that Japan currently imports "about $60 \%$ of its food on a caloric basis" and this paper shows that most of Nebraska's exports to Japan consist of food products, suggesting that Nebraska is a major source of those calories.

We also noted that Nebraska's food manufacturing exports were more important to the state's economy (based on RCA calculations comparing Nebraska to Japan) than Japan's manufacturing exports were to its economy. So, Nebraska's food manufactures exports are vital to keeping Nebraska's economy productive and competitive. The state, therefore, has an economic interest in continuing to promote and encourage trade with Japan.

\section{References}

1. Bela Balassa, "Trade Liberalization and 'Revealed' Comparative Advantage," Manchester School 33: 99-123, 1965.

2. Bela Balassa, "'Revealed' Comparative Advantage Revisited: An Analysis of Relative Export Shares of the Industrial Countries, 1953 - 1971, "Manchester School 45: 327-44, 1967.

3. CIA, World Fact Book, 2016: https://www.cia.gov/library/publications/the-world-factbook/

4. Marcus Noland, "'Revealed' Comparative Advantage in Japan and the United States," Journal of International Economic Integration, Vol. 4, No. 2, pp. 8-22, Autumn 1989.

\footnotetext{
${ }^{[9]}$ Avinash Dixit, "Prospects for High-Technology Industries and Trade Between the U.S. and Japan," paper presented at the MITI symposium on Cooperative Development of the Japanese and U.S., Economies, Tokyo; January 29-30, 1987; Vani V. Kotcherlakota and Yukichi Honda, "Research and Development Dynamics of High Tech Industry - Toward the Definition of Technology," Journal of Science Policy and Research Management, 1:65-74, 1986 and Fumio Kodama, "Technological Diversification in Japanese Industry," Science," 233:291-296, 1986.
} 
5. Avinash Dixit, "Prospects for High-Technology Industries and Trade Between the U.S. and Japan," paper presented at the MITI symposium on Cooperative Development of the Japanese and U.S., Economies, Tokyo, January 29-30, 1987.

6. EuCham Research Department, Compiled by Mai Nguyen 20151015@2015. "2015-11 Trade Openness Index EuCham European Chamber," 2015.

7. Fumio Kodama, "Technological Diversification in Japanese Industry," Science," 233:291-296, 1986.

8. Vani V. Kotcherlakota and M. Rittenhouse, "Index of Openness: Measurement and Analysis," The Social Science Journal 37(1):125-130, 2000.

9. Vani V. Kotcherlakota and Yukichi Honda, "Research and Development Dynamics of High Tech Industry - Toward the Definition of Technology," Journal of Science Policy and Research Management, 1:65-74, 1986.

10.Rolf J. Langhammer, 'Revealed comparative advantages in the services trade of the United States, the European Union and Japan: what do they tell us?" The Journal of World Investment \& Trade, ISSN 1660-7112, Vol. 5, Iss. 6, pp. 887-896, 2004.

11. Edward E. Leamer, Measures of Openness, National Bureau of Economic Research, (pp. 145-204), 1988. 2015 Trade Openness Index \& http://www.nber.org/chapters/c5850

12. Nebraska Department of Economic Development Website: http://opportunity.nebraska.gov/

13. United Kingdom, Depart. for Business Innovation \& Skills, BIS Performance Indicators, 2015.

14. U.S. Bureau of Census, International Data Base, 2016: http://www.census.gov/population/international/data/idb/informationGateway.php

15. USDOC, Bureau of the Census, International Trade Administration, 2016

16. USDOC, Bureau of the Census, USA Trade Online, 2016 https://usatrade.census.gov/

17. World Bank, World Development Indicators, 2016 http://data.worldbank.org/ 